\title{
REVIEW OF MARKETING SCIENCE
}

\section{EDITORS-IN-CHIEF}

Ernan Haruvy, The University of Texas at Dallas

Peter T.L. Popkowski Leszczyc, University of Queensland

\section{ASSOCIATE EDITORS}

Prof. Ashutosh Prasad, University of California - Riverside Prof. Yesim Orhun, University of Michigan

\section{DE GRUYTER}


ABSTRACTED/INDEXED IN Baidu Scholar · Cabell's Directory · CNKI Scholar (China National Knowledge Infrastructure) · CNPIEC: cnpLINKer · Dimensions · EBSCO (relevant databases) · EBSCO Discovery Service · EconBiz · ECONIS · EconLit · ERIH PLUS (European Reference Index for the Humanities and Social Sciences) · Genamics JournalSeek · Google Scholar · J-Gate · JournalGuide · JournalTOCs · KESLI-NDSL (Korean National Discovery for Science Leaders) · Microsoft Academic $\cdot$ Naviga (Softweco) $\cdot$ Norwegian Register for Scientific Journals, Series and Publishers · Primo Central (ExLibris) · Publons · QOAM (Quality Open Access Market) · ReadCube · Research Papers in Economics (RePEc) · SCImago (SJR) · SCOPUS · Sherpa/RoMEO · Summon (Serials Solutions/ProQuest) · TDNet · Ulrich`s Periodicals Directory/ulrichsweb · WanFang Data · WorldCat (OCLC)

ISSN 2194-5985 · e-ISSN 1546-5616

All information regarding notes for contributors, subscriptions, Open Access, back volumes and orders is available online at http://www.degruyter.com/roms.

RESPONSIBLE EDITORS Ernan Haruvy, The University of Texas at Dallas, 800 West Campbell Road, Richardson, TX 75080-3021, USA, Email: eharuvy@utdallas.edu

Peter T.L. Popkowski Leszczyc, University of Queensland, Email: p.popkowski@uq.edu.au

JOURNAL MANAGER Bendix Düker, De Gruyter, Genthiner Straße 13, 10785 Berlin,

Germany. Tel.: +49 (0)30 260 05-418, Fax: +49 (0)30 260 05-250,

Email: bendix.dueker@degruyter.com

RESPONSIBLE FOR ADVERTISEMENTS Claudia Neumann, De Gruyter, Genthiner Straße 13, 10785 Berlin, Germany. Tel.: +49 (0)30 260 05-226, Fax: +49 (0)30 260 05-322,

Email: anzeigen@degruyter.com

(C) 2019 Walter de Gruyter GmbH, Berlin/Munich/Boston

TYPESETTING Integra Software Service Pvt. Ltd, Pondicherry, India

PRINTING Franz X. Stückle Druck und Verlag e.K., Ettenheim

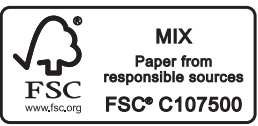




\section{Contents}

Vinay Goyal

Brand Image and its Determinants: A Stochastic Frontier Approach

Analysis - 1

Yair Orbach, Gila E. Fruchter and Naor Varsano

Taking a Ride on Mature Carrier Products to Push a New Technology: The Diffusion of Add-Ons 23

Saâd Mdarhri Alaoui and Amine Noureddine

The Impact Of Power And Relationship Quality On Value Creation and Appropriation in Buyer-Supplier Relationships - 47

Nina Baranchuk, Seethu Seetharaman and Andrei Strijnev

Revenue Sharing Vertical Contracts in the Movie Industry: A Theoretical Analysis - 81 